\title{
MISCELLANEOUS
}

THE Biblioteca "Luis Angel Arango," dependent on the Banco de la República, Colombia, has just been transferred to its new and magnificent edifice in downtown Bogotá. The new building is considered as a model of modernity and efficiency of its kind. The library, open to the general public, is undoubtedly one of the best of the country, and is realizing a great cultural task in Colombia.

\section{PERSONAL NOTES}

WOODROw BORAH of the University of California at Berkeley is spending his sabbatical leave in Seville and Rome in a search for archival material on colonial Mexico.

C. Harvey Gardiner will spend the summer in London and Madrid, gathering materials for his projected interpretive biography of William Hickling Prescott.

In January, 1959, Orlando Fals Borda was appointed Director General of the Ministry of Agriculture of Colombia. It is the first time that a professional sociologist occupies this position.

Sponsored by the New York University's Brazilian Institute, AlceU Amoroso Lima, visiting professor of Brazilian studies, gave a series of four public lectures on "Contemporary Life in Brazil" during the month of February.

\section{RECENT DEATHS}

Gregorio Arcila Robledo, O.F. M.

Died in Cali, Colombia, on December 27, 1958. This Franciscan historian of Colombia was born in San Francisco in the department of Caldas, Colombia, on August 20, 1890. In 1912 he entered the Franciscan Order. For many years he was director of the review Voz Franciscana (Bogotá), where he published numerous historical articles. He was a corresponding member of the Colombian Academy of History and of the Academy of American Franciscan History. Among his historical works are numbered the following: Fray Juan Martín (Bogotá, 1934); La Orden Franciscana en la América Meridional [in collaboration with the late Fr. Benjamin Gento Sanz of the Academy of American Franciscan History] (Rome, 1948); Las Misiones Franciscanas en Colombia (Bogotá, 1930); La Provincia Franciscana de Colombia. Las cuatro fuentes de su bistoria (Bogotá, 1953); Vida de Francisca de la Cruz del P.R.P.Fr. Rafael de la Serna (annotated 
edition; Medellin, 1950); Historia de la Orden Tercera de Cali (Cali, 1952); and Apuntes bistóricos de la Provincia Franciscana de Colombia (Bogotá, 1953).

William F. Montavon

Died in Washington, D.C. on February 15, 1959. Holder of two papal decorations, Dr. Montavon was director of the legal department of the National Catholic Welfare Conference from 1925 until his retirement in 1951. Born in Ohio, he received his education at the University of Notre Dame, the Institute of St. Croix in Paris, and the Catholic University of Washington, D.C. Dr. Montavon made a specialty of Latin American legal problems in his early career. He served the Commerce Department as commercial attaché in Peru, Bolivia, and Ecuador, and accompanied the Forbes Commission to Haiti to plan the withdrawal of United States forces there in 1930. In 1941 he was named to the advisory committee of Nelson A. Rockefeller's Office of Inter-American Affairs. St. Bonaventure University, Olean, New York, awarded him its Catholic Action Medal in 1939. He was also an Advisory Editor of THE AMERICAS until 1956. 